\title{
Studies on Human Milk Macrophages: Effect of Activation on Phagocytosis and Secretion of Prostaglandin $\mathrm{E}_{2}$ and Lysozyme
}

\author{
H. BLAU, J. H. PASSWELL, ${ }^{(27)}$ M. LEVANON, J. DAVIDSON, F. KOHEN, AND B. RAMOT
}

Departments of Pediatrics and Hematology, Chaim Sheba Medical Center, Tel-Hashomer and Sackler School of Medicine Tel-Aviv University and the Department of Hormone Research, Weizmann Institute Rehovot, Israel.

\begin{abstract}
Breast milk macrophages cultured in vitro synthesized and secreted increasing amounts of protein, lysozyme, and prostaglandin $\mathrm{E}_{2}\left(\mathrm{PGE}_{2}\right)$ into the extracellular medium. These cells were also shown to actively phagocytose labeled zymosan particles in culture. Morphologic characteristics, phagocytosis, and secretory responses of the macrophages were altered depending on the presence of various stimuli in the culture. Concanavalin A, endotoxin and zymosan particles, but not latex particles, all resulted in an increased $\mathrm{PGE}_{2}$ secretion into the medium. Although total protein synthesis was not altered by any of these stimuli, Concanavalin $\mathbf{A}$ and endotoxin resulted in a decreased lysozyme concentration in the extracellular medium. Concanavalin $A$ enhanced, whereas endotoxin and prior phagocytosis of latex particles inhibited phagocytosis of labeled zymosan particles. These findings indicate that phagocytosis and secretions of milk macrophages may be altered depending on the nature of the stimulating agent.
\end{abstract}

Abbreviations

BSA, bovine serum albumin

PBS, phosphate buffered saline

PGE, prostaglandin E

Breast milk feeding is preferred in all infants because of its antimicrobial properties $(8,25)$, biochemical and nutritional suitability (6), and protective effect against necrotising enterocolitis (16). Epidemiologic studies also have shown that breast milk fed infants have less allergic disease (7). Some of the beneficial effects of breast milk have been attributed to the presence of proteins such as immunoglobulin A $(11,23)$, lactoferrin (1), and lysozyme (10). In addition, large numbers of viable cells are present in human breast milk (15). Eighty percent of these cells have been identified as macrophages (20) which are capable of phagocytosis (19) and microbiocidal activity $(15,19)$

The current studies were undertaken to assess the milk macrophage as a functioning cell. We have examined some of the secretory products (total protein, prostaglandin $\mathrm{E}_{2}$ and lysozyme) and morphologic characteristics after stimulation of these cells in vitro, either by nonspecific stimuli (latex or zymosan particles; endotoxin) or Concanavalin A which binds to a specific membrane receptor (21). In addition, the effects of these stimuli on phagocytosis were determined.

\section{MATERIALS AND METHODS}

Human milk was collected from nursing mothers, 3-10 days postpartum, by hand expression. It was kept at room temperature in a sterile container and cultured within $2 \mathrm{hr}$.

Macrophage monolayers. Seven and one-half $\mathrm{ml}$ of milk was layered onto a $2.5 \mathrm{ml}$ Ficoll-Hypaque cushion and centrifuged at $1400 \mathrm{rpm}$ for $25 \mathrm{~min}$. The mononuclear cell layer was washed three times in phosphate buffer saline (PBS) and resuspended at a concentration of $1 \times 10^{6}$ cells per ml in RPMI-1640 supplemented with streptomycin $(100 \mathrm{mcg} / \mathrm{ml})$, penicillin (100 units $/ \mathrm{ml}$ ) and $10 \%$ heat-inactivated, dialysed, and millipore-filtered fetal calf serum (Lapidot Rehovot) (complete medium). Four-tenths ml of this cell suspension was added to each well of tissue culture plates (16-mm well diameter) (Costar, Cambridge, MA) and gently rocked at $37^{\circ} \mathrm{C}$ for $1 \mathrm{~h}$. The nonadherent cells were removed by vigorous washing and the monolayers were cultured in $0.5 \mathrm{ml}$ of complete medium at $37^{\circ} \mathrm{C}$ in a humidified atmosphere of $5 \% \mathrm{CO}_{2}$ in air. At the start of the culture, the monolayers were treated with various stimulating agents diluted in RPMI. At termination, culture medium was harvested and stored at $-20^{\circ} \mathrm{C}$ for subsequent assays.

For comparison, we cultured human blood monocytes for 7 days after which they acquired characteristics of macrophages (designated "blood derived macrophages").

Stimulating agents. Concanavalin A (Calbiochem, San Diego, CA) and endotoxin (lipopolysaccharide B from E coli B4 No. 0111, Difco Labs, Detroit, MI) were dissolved in RPMI and millipore filtered before use. Latex particles $(1.1 \mu \mathrm{m}$ diameter $)$ (Dow Chemical Co., Indianapolis, IN) were washed three times and sterilized under a UV light source and stored at $4^{\circ} \mathrm{C}$ until used. Zymosan particles $\left(5 \times 10^{7} /\right.$ culture) were boiled for $1 \mathrm{~h}$ and added directly. Indomethacin $(5 \mu \mathrm{g} / \mathrm{ml})$ (Merck, Sharpe \& Dohme, West Point, PA) was added to cultures $1 \mathrm{~h}$ before addition of the stimulating agents.

Lysozyme assay. Lysozyme was assayed by determining the initial rate of lysis of a suspension of micrococcus lysodekticus (Sigma) in $1 \mathrm{~m}$ acetate buffer $\mathrm{pH} 6.2$ at room temperature with the aid of a spectrophotometer fitted with an automatic recorder. Egg white lysozyme (Sigma) was used as a standard (4).

Cell morphology. Monolayers in individual Petri dishes were stained with Giemsa, nonspecific esterase, Sudan III and periodic acid schiff stains by standard laboratory procedure.

Prostaglandin $E_{2}$ assay. Supernatants were assayed for $\mathrm{PGE}_{2}$ content by radioimmunoassay. Formed complexes were separated from free radioactive $\mathrm{PGE}_{2}$ by dextran-coated charcoal. This assay detects $10 \mathrm{pg}$ of $\mathrm{PGE}_{2} /$ tube and the antiserum shows no cross reactivity with $F$ prostaglandins (Rabbit anti-PGE-BSA Serum, Cat. No. 61-355, Miles Yeda, Kiryat Weizmann, Rehovot).

Phagocytosis assay. Zymosan particles (Immunologic reagent, ICN Pharmaceuticals Inc., Cleveland, $\mathrm{OH}$ ) were labeled as follows: after oxidation with sodium metaperiodate $(0.02 \mathrm{M}, 5 \mathrm{ml})$ in $0.5 \mathrm{M}$ sodium acetate buffer, $\mathrm{pH} 4.5$ for $60 \mathrm{~min}$, and repeated washing, the zymosan particles $(50 \mathrm{mg})$ were reduced with sodium boro- $\left[{ }^{3} \mathrm{H}\right]$-hydride $10 \mathrm{mCi}$ (156 mCi/mg) (Radiochemical Center, Amersham, England) for $12 \mathrm{~h}$. Excess borohydride was removed by adjusting the $\mathrm{pH}$ to 5 with acetic acid. $0.1 \mathrm{M}$ hydroxylamine was then added for $30 \mathrm{~min}$ at room temperature (Method of Bar Shavit, Z. and Goldman, R., Dept. of Membrane Research, Wiez- 


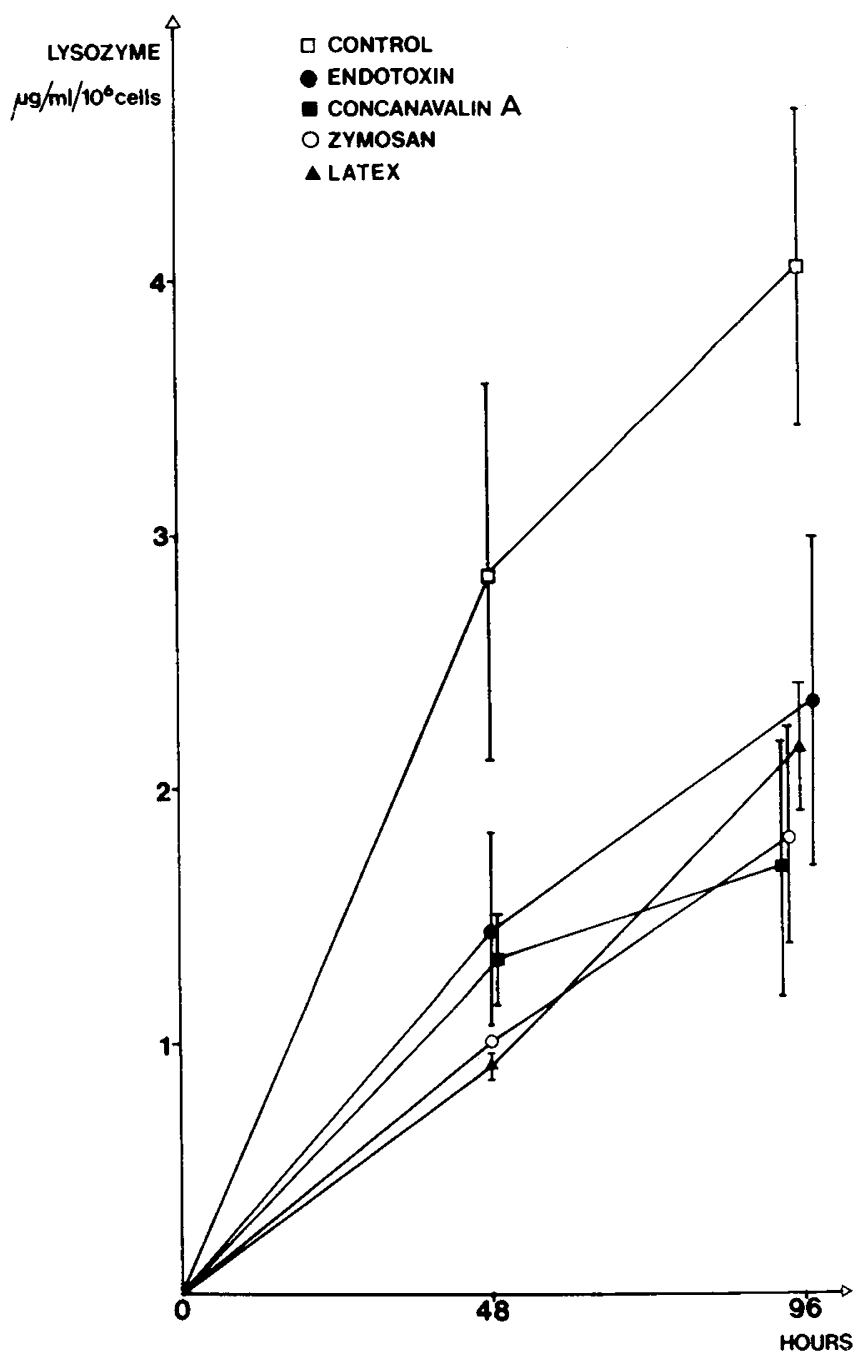

Fig. 1. The kinetics of lysozyme production by milk macrophages is compared in the continuing presence of various stimuli to that of unstimulated cells. Each point represents the mean \pm S.E. of duplicate cultures in two separate experiments.

mann Institute of Science, Rehovot, Israel). The particles were then washed extensively and stored in PBS at $-20^{\circ} \mathrm{C}$ until used.

In preliminary experiments, we showed that there was a gradual increase and eventual plateau of uptake at $120 \mathrm{~min}$. Therefore, milk macrophage monolayers were incubated for $120 \mathrm{~min}$ with labeled zymosan particles $\left(5 \times 10^{7} /\right.$ culture $)$ under different experimental conditions. Wells were then washed gently with PBS until free of unphagocytosed zymosan. This was observed carefully between washes under the inverted microscope. Cells were lysed with $1 \%$ sodium dodecyl sulfate (Sigma) and radioactivity was measured.

Assay of $p H$ variation. $0.1 \mathrm{~N} \mathrm{NaOH}$ or $0.1 \mathrm{~N} \mathrm{HCl}$ was added gradually in order to adjust $\mathrm{pH}$ from 3 to 9 . This medium was millipore filtered and added to successive wells for $30 \mathrm{~min}$. Percentage cell viability was assessed by trypan blue exclusion.

Protein synthesis and secretion assay. $\left[{ }^{3} \mathrm{H}\right]$-Leucine $(324 \mathrm{mCi} /$ mmole) (Radiochemical Centre, Amersham, England) was added to the culture medium at the onset of the experiment. At termination, $0.1-\mathrm{ml}$ aliquots of medium were removed and proteins were precipitated with cold trichloracetic acid (10\%). After washing, the precipitate was dissolved in $1 \mathrm{~N} \mathrm{NaOH}$ and radioactivity measured.

DNA assay. The adherent cell layer was lysed with $1 \%$ sodium dodecyl sulfate (Sigma) and aliquots of cell lysates were assayed for DNA content by a fluorimetric assay, as described previously (2).

\section{RESULTS}

Lysozyme secretion. The concentration of the lysozyme in the extracellular medium progressively increased to $4 \mu \mathrm{g} / \mathrm{ml} / 10^{6}$ cells by $96 \mathrm{~h}$. This was less than the $8-15 \mu \mathrm{g} / \mathrm{ml} / 10^{6}$ cells found in medium from blood-derived macrophage cultures during similar culture periods. The lysozyme concentration of the extracellular medium was less after addition of all the stimuli used (Fig. 1).

Protein assay. De novo protein synthesis and secretion into the medium increased during the period of culture. Addition of the various stimuli did not alter the rate of total protein synthesis (Fig. 2).

Prostaglandin $E_{2}$ secretion. Milk macrophages secreted $\mathrm{PGE}_{2}$ during culture. Basal levels at $48 \mathrm{~h}$ ranged from $0.5-1 \mathrm{ng} / \mathrm{ml} / 10^{6}$ cells. These concentrations were similar to those found in macrophages derived from human blood and mouse peritoneal macrophage cultures $(12,13)$. Milk macrophage $\mathrm{PGE}_{2}$ secretion increased 3-10-fold with addition of either concanavalin $A$ or endotoxin or zymosan to the culture medium, but no increase was observed after addition of latex particles (Fig. 3A). Similar results were obtained after $120 \mathrm{~h}$ of culture (Fig. 3B). Prior addition of indomethacin inhibited the $\mathrm{PGE}_{2}$ production of stimulated macrophage monolayers (Table 1 ).

Quantitation of phagocytosis. The time course of phagocytosis of labeled zymosan particles by milk macrophages is illustrated in Figure 4. Zymosan phagocytosis by milk macrophages was of the same order of magnitude as that of blood monocytes. There was no change in the extent of phagocytosis over the 24-h culture

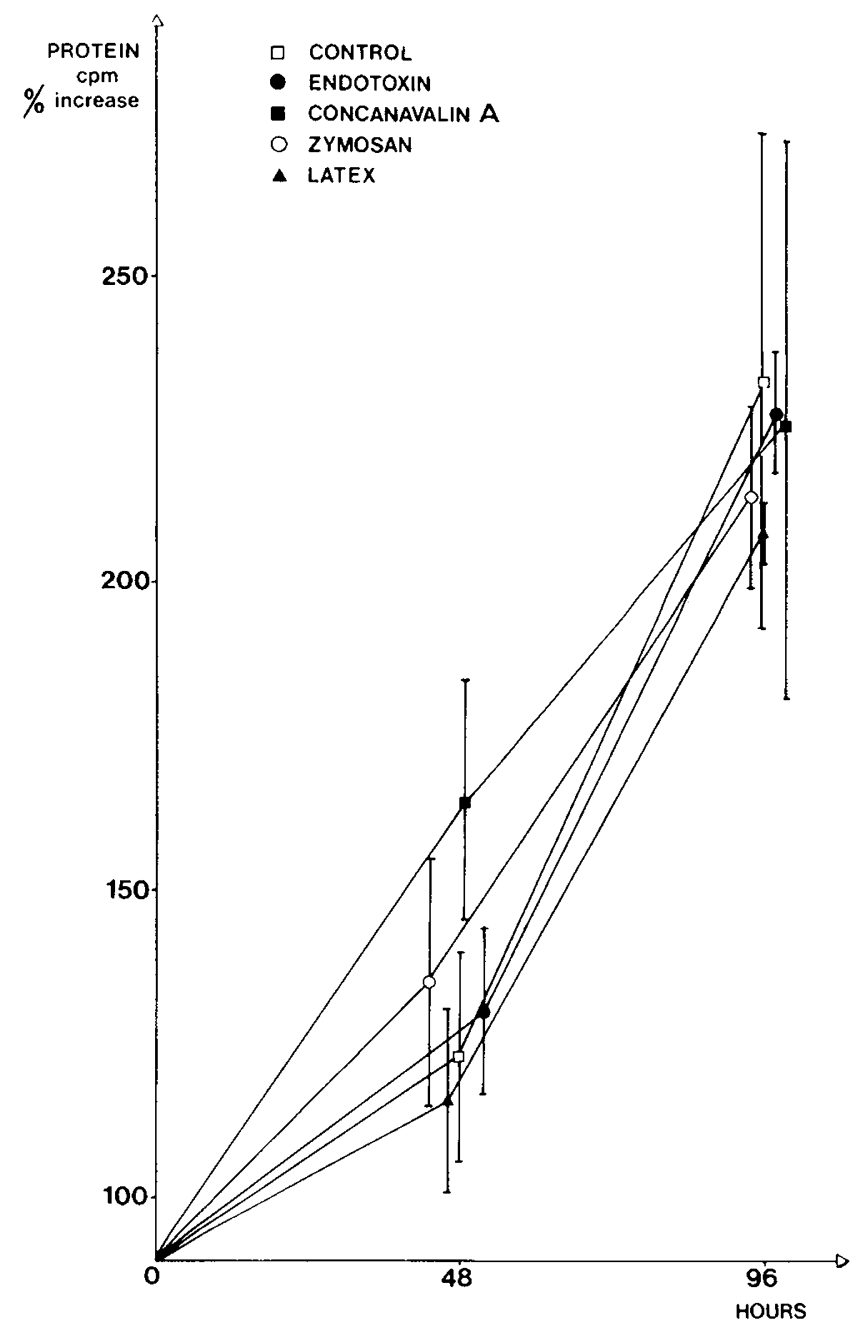

Fig. 2. Kinetics of de novo protein synthesis by macrophages treated with various stimuli in culture. Each point represents the mean \pm S.E. of duplicate cultures in two separate experiments. 
A

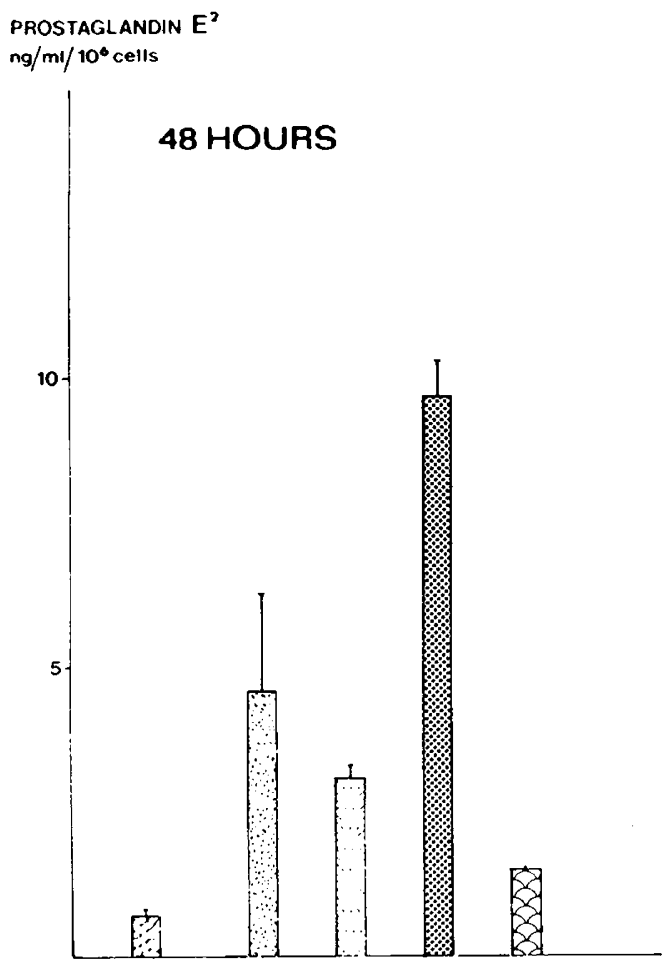

B

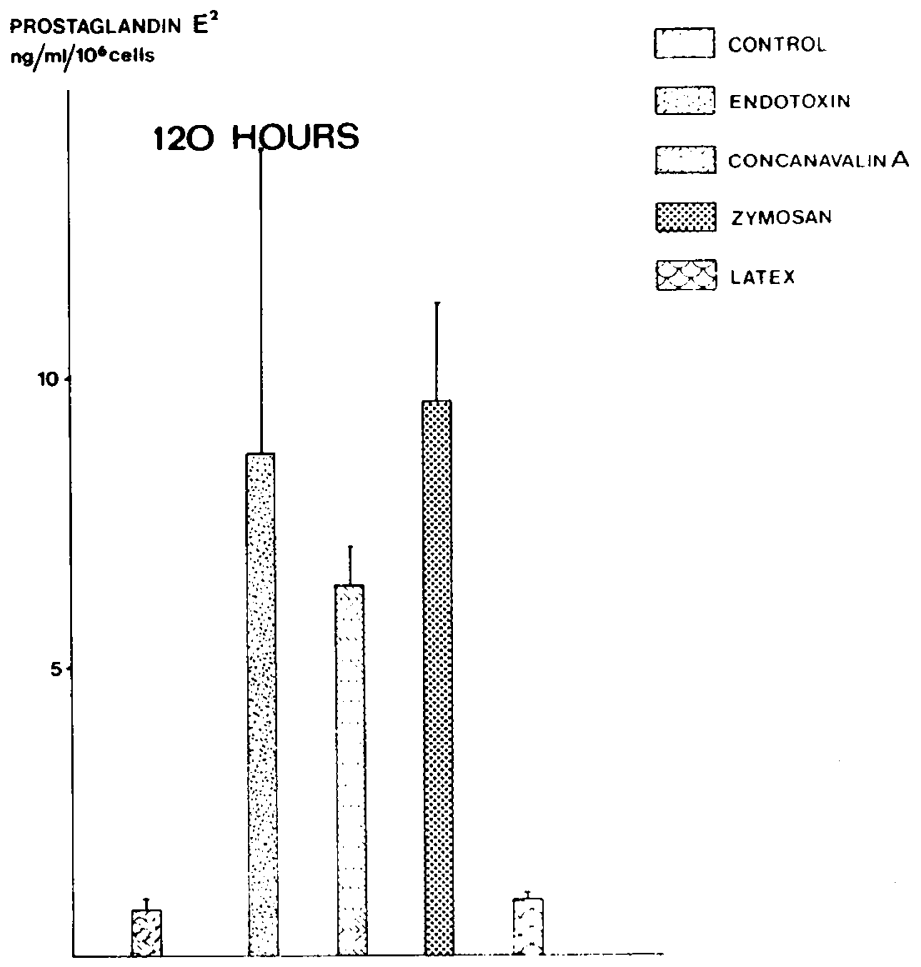

Fig. 3. Prostaglandin $\mathrm{E}_{2}$ production by macrophages in culture after incubation in the presence of various stimuli $(A)$ after $48 \mathrm{~h}$ and $(B)$ after $120 \mathrm{~h}$ in culture. Each point represents the mean \pm S.E. of three duplicate cultures.

Table 1. Effect of indomethacin on $P G E_{2}$ production by breast milk macrophages ${ }^{1}$

\begin{tabular}{lcc}
\hline Culture conditions & $\begin{array}{c}\text { Indomethacin } \\
(5 \mu \mathrm{g} / \mathrm{ml})\end{array}$ & $\begin{array}{c}\mathrm{PGE}_{2} \\
(\mathrm{ng} / \mathrm{ml} / \text { culture })\end{array}$ \\
\hline Control & - & 0.5 \\
& + & 0.4 \\
+ Concanavalin A & - & 15.5 \\
$(50 \mu \mathrm{g} / \mathrm{ml})$ & + & 0.3 \\
+ Endotoxin & - & 10.0 \\
$(20 \mu \mathrm{g} / \mathrm{ml})$ & + & 0.9 \\
+ Zymosan & - & 18.0 \\
$\left(1 \times 10^{7}\right.$ particles/ml $)$ & + & 0.4 \\
\hline
\end{tabular}

${ }^{1}$ Each result represents the average of duplicate cultures from a single experiment. Variation of the duplicates was less than $10 \%$.

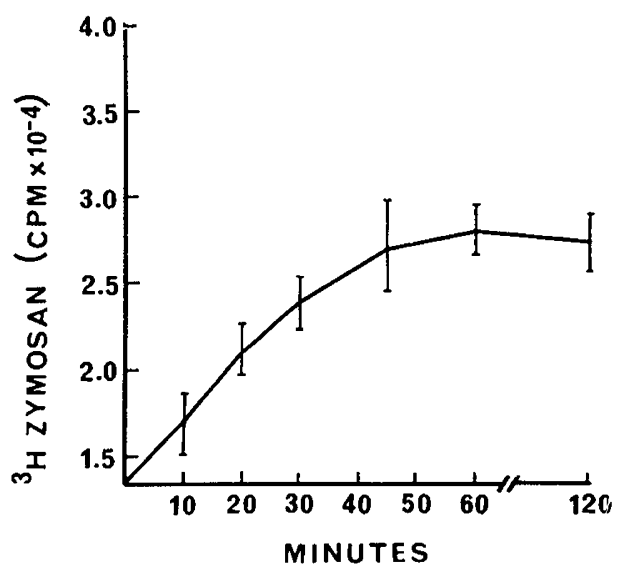

Fig. 4. The kinetics of the uptake of $\left[{ }^{3} \mathrm{H}\right]-z y m o s a n$ by milk macrophages. period. Concanavalin A increased phagocytosis 4 -fold after $2 \mathrm{~h}$ in culture and up to 7 -fold after $24 \mathrm{~h}$. This increase was dose dependent (Fig. 5). Both prior phagocytosis of latex particles and addition of endotoxin to the culture medium caused a slight decrease in phagocytosis (Fig. 5).

$D N A$ assay. In order to verify that there were similar numbers of adherent cells under the different experimental conditions, DNA content of the adherent monolayer was measured in some experiments. There were similar numbers of cells in unstimulated monolayers as in those stimulated with endotoxin or latex particles. Monolayers exposed to concanavalin A had 1.5 times the concentration of DNA, indicating that this ligand slightly increased adherence ( $1 \mu \mathrm{g}$ of DNA was equivalent to approximately $0.5 \times 10^{6}$ cells).

Morphology. The monolayer consisted of macrophages as indicated by positive non-specific esterase granules, ability to phagocytose latex and zymosan, and rosette formation with complementcoated zymosan. After $1 \mathrm{~h}$, the cells were rounded with numerous lipid-laden vacuoles. At $48 \mathrm{~h}$, the cells had spread avidly, and were fusiform in shape. Treatment with concanavalin A resulted in giant cell formation with large endocytic vacuoles, as previously described (14). These vacuoles contained lipid, as shown with a Sudan III stain.

$\mathrm{pH}$ variation. Less than $5 \%$ of the cells remained viable at $\mathrm{pH}$ 3-5. At $\mathrm{pH} \mathrm{7,97 \%} \mathrm{were} \mathrm{viable} \mathrm{whereas} \mathrm{at} \mathrm{pH} \mathrm{9,87.5 \%} \mathrm{still}$ excluded trypan blue (Table 2).

\section{DISCUSSION}

We found that human milk macrophages are viable and actively synthesize and secrete various products in culture. Increasing concentrations of $\mathrm{PGE}_{2}$ and lysozyme were found in the medium and increasing de novo protein synthesis was observed during the period of culture. These macrophages also phagocytosed increasing amounts of labeled zymosan particles, reaching a plateau after $2 \mathrm{~h}$ of incubation. 

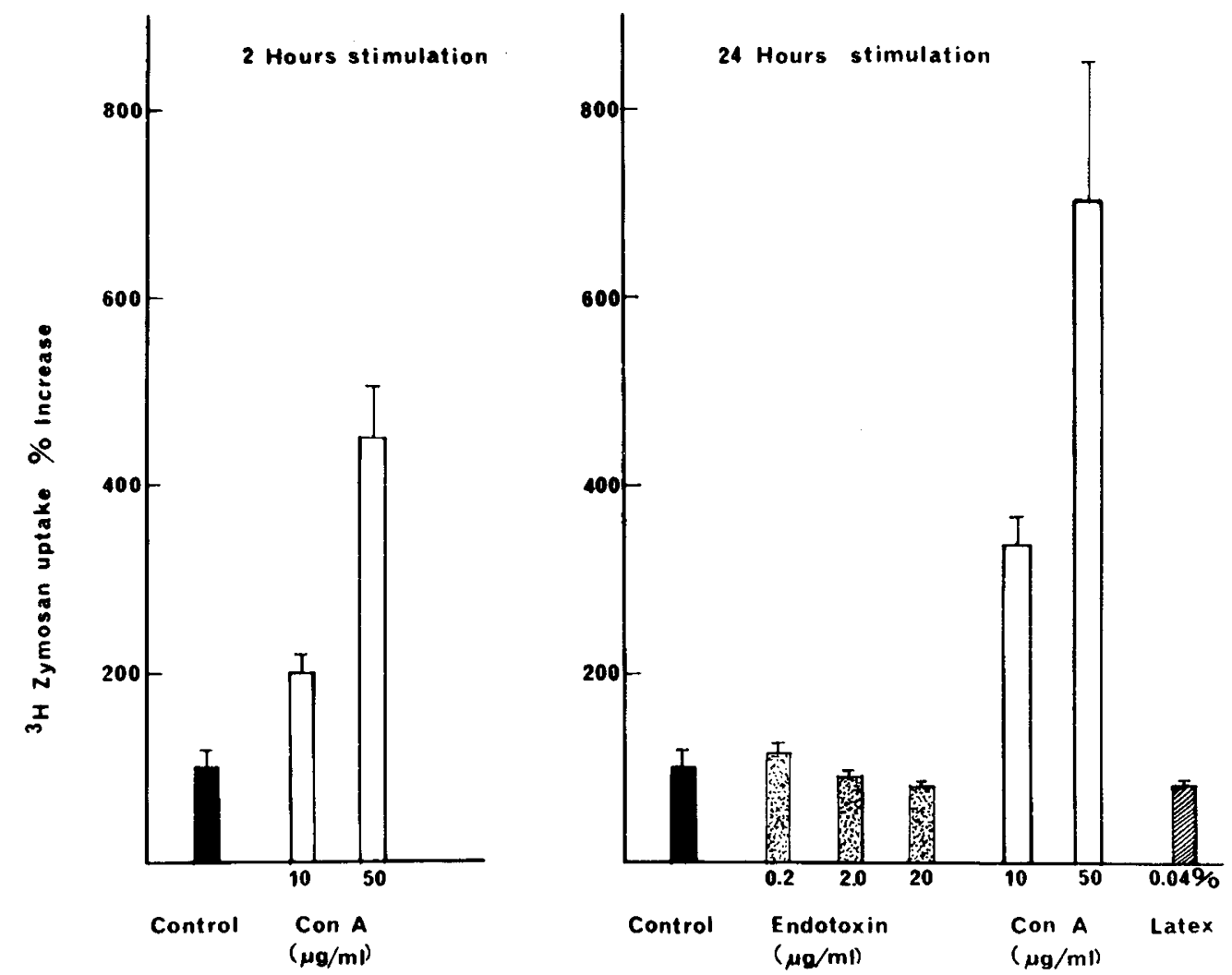

Fig. 5. The extent of phagocytosis of labeled zymosan particles by macrophages incubated with different stimuli, as compared with unstimulated cells. (Left hand panel), after $2 \mathrm{~h}$ stimulation and (right hand panel), after $24 \mathrm{~h}$ stimulation. Cells were exposed to zymosan for $120 \mathrm{~min}$. Each point is the mean \pm S.E. of triplicate cultures in two separate experiments.

Table 2. Effect of varying $p H$ of culture medium on viability of macrophages-percentage of cells excluding Trypan blue dye after $30 \mathrm{~min}$ in culture

\begin{tabular}{lrrrrrrr}
\hline pH medium & 3 & 4 & 5 & 6 & 7 & 8 & 9 \\
$\%$ viability & 4 & 6 & 3 & 16 & 97 & 92 & 88
\end{tabular}

These functions were changed depending on the stimuli used. Zymosan, endotoxin, and concanavalin A stimulated $\mathrm{PGE}_{2}$ secretion, but resulted in a decreased lysozyme concentration in the extracellular medium. Concanavalin A caused a marked increase in phagocytosis whereas endotoxin caused a slight decrease in phagocytosis. Latex particles did not alter $\mathrm{PGE}_{2}$ secretion but decreased phagocytosis of zymosan particles, possibly as a competitive effect. The constant increase in protein synthesis under all conditions of culture indicates that the cells were viable. The decrease in lysozyme concentration in the extracellular medium may have been due to a selective decrease in synthesis or an inhibiting factor produced after stimulation. The alteration of phagocytosis did not correlate with changes in $\mathrm{PGE}_{2}$ and hence modulation of phagocytosis by PGE proposed with murine macrophages is unlikely to have been a factor in these experiments (17). The ability to selectively alter function, which we have demonstrated, may be relevant in vivo, when the milk macrophage encounters various environmental stimuli.

Prostaglandins, especially $\mathrm{PGF}_{2 \alpha}$ have recently been shown to be markedly elevated in human breast milk and were absent in cow's milk $(9,18)$. Our studies show that the milk macrophage is an important source of prostaglandin $\mathrm{E}_{2}$. Although $\mathrm{PGE}_{2}$ is the major prostaglandin secreted by human blood monocytes in culture (13), it should be of interest to examine whether this is the case with macrophages from other sites. The clinical significance of prostaglandin production by milk macrophages is as yet unclear. $\mathrm{PGE}_{2}$ increases intestinal motility and may be responsible for the increased number of bowel movements in breast fed babies. Furthermore, the action of $\mathrm{PGE}_{2}$ on target cells is usually attributed to its enhancement of adenylate cyclase activity and subsequent increase in cyclic AMP levels (14). Indeed, other investigators have shown that $\beta$ adrenergic hormones and cyclic AMP analogues stimulate intestinal glycoprotein synthesis in vitro (3). Because macrophage products including $\mathrm{PGE}_{2}$ affect both the induction and suppression of the immune response (22), these ingested macrophages may have a role in the development of the local immune response of the small bowel.

It should be noted that milk macrophages remained viable in alkali conditions comparable to those of the small intestine. Although they did not survive at low $\mathrm{pH}$, they are probably protected from gastric acidity in vivo, as colostrum has been shown to buffer gastric acidity to $\mathrm{pH} 6$ (25). Macrophage products could exert their local effects on the bowel even if the macrophages themselves do not survive local conditions.

In vivo experiments have shown that colostrum stimulates neonatal intestinal mucosal growth (5) and decreases the permeability of protein molecules across the intestinal barrier in experimental animals (24). Further studies may lead to the recognition of specific molecular species capable of exerting local effects on intestinal function.

\section{REFERENCES AND NOTES}

1. Bullon, J. J., Rogers, H. J., and Leigh, L.: Iron binding proteins in milk and resistance to E. coli infection in infants. Br. Med. J., 1: 69 (1972).

2. Einstein, L. P., Schneeberger, E. E., and Colten, H. R.: Synthesis of the second component of complement by long term primary cultures of human monocytes. J. Exp. Med., 143: 114 (1976).

3. Forstner, G., Shih, M., and Lukie, B.: Cyclic AMP and intestinal glycoprotein synthesis: the effect of B adrenergic agents, theophylline and dibutyryl cyclic AMP. Can. J. Physiol. Pharmacol., 5I: 122 (1973)

4. Gordon, S., Todd, J., and Cohn, L. A.: In vitro synthesis and secretion of lysozyme by mononuclear phagocytes. J. Exp. Med., 139: 1228 (1974). 
5. Heird, W. C. and Hansen, I. H.: Effect of colostrum on growth of intestinal mucosa. Pediatr. Res. (abstract), 11(1): 406 (1977).

6. Jellife, D. E. and Jellife, E. F. P.: Current concepts in nutrition: "breast is best"modern meanings. N. Engl. J. Med., 297: 912 (1977).

7. Jellife, E. F. P.: Infant feeding practices: associated iatrogenic and commerciogenic diseases. Pediatr. Clin. N. Am., 24(I): 49 (1977).

8. Kleinman, R. E. and Walker, W. A.: The enteromammary immune system: an important new concept in breast milk host defence. Dig. Dis. Sci., 24(11): 876 (1979).

9. Lucas, A. and Mitchell, M. D.: Prostaglandins in human milk. Arch. Dis. Child., 55: 950 (1980).

10. Miller, T. E.: Killing and lysis of gram negative bacteria through the synergistic effect of hydrogen peroxide, ascorbic acid and lysozyme. J. Bacteriol., 98: 949 (1969).

11. Nagura, H., Nakane, P., and Brain, W. R.: Breast milk IgA binds the jejunal epithelium in suckling rats. J. Immunol., 120: 1333 (1978).

12. Passwell, J. H., Dayer, J. M., Gass, K. and Edelson, P. J.: Regulation by Fc fragments of the secretion of collagenase, $\mathrm{PGE}_{2}$ and lysozyme by mouse peritoneal macrophages. J. Immunol., 124(1): 910 (1980).

13. Passwell, J. H., Dayer, J. M., and Merler, E.: Increased prostaglandin production by human monocytes after membrane receptor activation. J. Immunol., 123: 115 (1979).

14. Passwell, J. H., Goldring, S. R., and Dayer, J. M.: Effects of concanavalin A and Fc fragments on human monocyte cyclic AMP content: modulation of monocyte secretory functions by cyclic AMP. Immunology, 46: 415 (1982)

15. Pitt, J.: Milk mononuclear phagocyte. Pediatrics (suppl), 64: 745 (1979)

16. Pitt, J., Barlow, B., and Heird, W. C.: Protection against experimental necrotising enterocolitis by maternal milk. 1. Role of milk leucocytes. Pediatr. Res., II:

Copyright (C) 1983 International Pediatric Research Foundation, Inc. $0031-3998 / 83 / 1704-0241 \$ 02.00 / 0$
906 (1977).

17. Razin, E., Bauminger, S., and Globerson, A.: Effect of prostaglandins on phagocytosis of sheep erythrocytes by mouse peritoneal macrophages. J. Reticuloendothel. Soc., 23: 237 (1977).

18. Reid, B., Smith, J., and Friedman, Z.: Prostaglandins in human milk. Pediatrics, 66(6): 870 (1980).

19. Robinson, J. E., Harvey, B. A. M., Soothill, J. F.: Phagocytosis and killing of bacteria and yeast by human milk cells after opsonisation in aqueous phase of milk. Br. Med. J., 1: 1443 (1978).

20. Smith, C. W. and Goldman, A. S.: Cells of human colostrum. 1. In vitro studies of morphology and function. Pediatr. Res., 2: 103 (1968).

21. Smith, C. W. and Goldman, A. S.: Macrophages from human colostrum. Exp. Cell Res., 66: 317 (1977).

22. Stenson, W. F. and Parker, C. W.: Prostaglandins, macrophages and immunity. J. Immunol., 125(1): 1 (1980).

23. Tomasi, T. B.: Secretory immunoglobulins, N. Engl. J. Med., 287: 500 (1972).

24. Udall, J. N., Colony, P., Fritze, L., Pang, K Trier, J. S., and Walker, W. A. Development of the gastrointestinal mucosal barrier, 11. The effect of natural versus artificial feeding on intestinal permeability to macromolecules. Pediatr. Res., 15(3): 245 (1981).

25. Welsh, J. K. and May, J. T.: Anti-infective properties of breast milk. J. Pediatr., 94(I): 1 (1979).

26. Informed consent was obtained from the mothers who donated breast milk samples.

27. Address reprints to: J. Passwell, Division of Pediatrics, Chaim Sheba Medical Center, Tel-Hashomer, Israel. 52621.

28. Received for publication October 2, 1981

29. Accepted for publication August 27, 1982. 